\title{
Investigating the Organizational Climate of Secondary Schools in Khyber Pakhtunkhwa, Pakistan
}

\author{
Abdur Rahman \\ Ph. D Scholar, Institute of Education \& Research, University of Peshawar. \\ Arshad Ali \\ Professor, Institute of Education \& Research, University of Peshawar.
}

Received on: 13-10-2021

Accepted on: 14-11-2021

\begin{abstract}
Secondary schools are responsible for the provision of quality education in preparing graduates of the institutions for higher learning and semi-skilled employees for working in various enterprises of the society. Organizational climate is a key element that determines the efficient role of secondary schools in the education sector. Considering the significance of the organizational climate in secondary schools, the study aimed to investigate the organizational climate of secondary school in Khyber Pakhtunkhwa, Pakistan. The study was descriptive survey design with population of 2639 principals and 39182 teachers of secondary schools. Samples of 50 heads and 326 teachers were selected with cluster random sampling. A validated and reliable tool, organizational climate description questionnaire for heads and teachers was used while data were collected personally from respondents. Data were analyzed with percentages, mean, standard deviation, Pearson correlation and linear regression. The study highlighted that majority of the principals had directive behavior, dominated meetings and ruled with iron hands, teachers' behaviors were frustrated and schools were vulnerable to external political pressures. The study recommended that Organizational climate is relatively a new field, therefore; it may be taught as a subject in all teachers' training institutions and in education departments/faculties of the universities to develop conceptual knowledge of the educational leaders and teachers. At present Educational Monitoring Authority (EMA) did not include organizational climate as an indicator for the schools' development/progress. So, the government may explicitly include organizational climate in the evaluation system of the schools.
\end{abstract}

Keywords: Investigation, Organizational Climate, quality education, Khyber Pakhtunkhwa, population, study, Educational Monitoring Authority.

\section{Introduction}

Public organizations are the most important components of a country's economy and the most important components of its infrastructural development (Vashdi, Vigoda-Gadot, \& Shlomi, 2013). Even though these organizations are frequently excoriated for a lack of a highly innovative and novel environment, as well as a bureaucratic style, a strong influential 
Vol. II, Issue 3, Oct - December 2021

ISSN No: (ONLINE): 2710-043

www.irjei.com
International Research Journal of Education and Innovation

ISSN No: ISSN (PRINT): 2710-0448

DOI: https://doi.org/10.53575/irjei.v2.03(21)6.67-78

Investigating the Organizational Climate of Secondary Schools ...

way of management, directives from both political and bureaucratic officials, and an ou pas way of performing duties (Borins 2000; Vigoda-Gadot \& Kapun, 2005). Managers and planners in organizations are driven to renovate the old autocratic style of administration and construct an organizational model that fosters creativity, devotion, uniform communication, self-sufficiency, and accountability (Vigoda \& Golembiewski, 2001). Only through enhancing the constructive, optimistic, positive, and creative organizational environment in public organizations can the organizational process and administrative procedure be improved (Andrews, Boyne, \& Walker, 2011). According to Armstrong (2003), organizational climate is a social composition that fosters or hinders collaboration, thus it may be viewed as a barrier between personal skill and inspiration and the many occupational avalanche repercussions. Schools' climate, according to Schneider, González-Romá, Ostroff, and West (2017), refers to the characteristics of a school that create a vibrant learning environment, care for parents and children's ambitions and hopes, awaken teachers' inventiveness and zest, and promote staff members' quality and performance. It is essentially the institute's attitude that inspires students, professors, managers, and other school staff to love school and be positive. The atmosphere of a school is the characteristic of an institution that allows each individual to see his or her own worth, self-esteem, and significance while also fostering a sense of belonging to something larger than us. According to Osman and Kamis (2019), school climate may either encourage flexibility or create a risk for individuals who execute their responsibilities and study in that setting, because climate refers to the aspects of the organization that are purposefully shown by the school personnel (Armstrong, 2003).

According to Hoy and Miskel (2008), school environment is a fairly long-term feature of the whole school that is observed by its people and can explain their accumulative perception of habitual performance as well as affect their demeanor and strategy with in institutions. The spirit and soul of an institution, as well as psychological and expressive characteristics, are what give a school its personality. The climate of the school, according to McCarley, Peters, and Decman (2016), is a detectable output of every aspect of the institution, the extent of the endeavor, the staff, the architectural engineering and atmosphere, traditions and norms, the managerial arrangement, and the impact of human relationships on the feelings, inspirations, and educational outcomes of all personnel who perform their duties in that organisation. It establishes the school's basis and vision, as well as providing clarity for the educational institutes' activities and procedures, which have a direct impact on educators and students' motivations and successes. The atmosphere of the school, according to Adejumobi and Ojikutu (2013), is a broad concept that is impacted by the school's professors, ministerial staff, leadership, and management behaviors in educational institutions. The climate in schools is a fairly long-lasting excellence of the working environment that is recognized by educators, manipulates worker performance, and is based on cumulative discernment (Maamari\& Majdalani, 2017). Differentiating between various schools' organizational climates Halpin classified school organizational climates into three categories (Pretorius \& De Villiers ,2009).

If somebody visits a number of schools, comments promptly how various schools have different feel. In some schools the educators and the directors are enthusiastic and show self-reliance in what they are performing. They feel proud and zest for working in collaboration and that zest 
Vol. II, Issue 3, Oct - December 2021

ISSN No: (ONLINE): 2710-043

www.irjei.com
International Research Journal of Education and Innovation

ISSN No: ISSN (PRINT): 2710-0448

DOI: https://doi.org/10.53575/irjei.v2.03(21)6.67-78

Investigating the Organizational Climate of Secondary Schools ...

and pleasure is transferred to the children. In another school the profound discontent of the educators is conspicuous; the director tries to conceal his ineffectiveness and lack of confidence under the cloak of dictatorship. The psychological illness of such type of staff members reflect on the learners who, through their own exasperation, response to the educators with a state of despondency. The third type of institution is not distinctive by delight or by desolation, but distinguishes by empty ritual...in an extraordinary manner the evidences do not appear to be real (p.17).

Organizational climate is the cohesive insight, sentiments, as well as strategy that organizational members have about the organization's basic essentials, which duplicate the recognized standard, philosophies, and perspectives of the corporate culture and affects the members' manners and attitudes in an optimistic or pessimistic manner (Okoli, 2018). Healthy organizational climate refers to how conducive the working environment is for employees, which has a direct impact on the organization's success (Ghanbari \& Eskandari, 2015). Over and beyond novelty and job satisfaction, according to Rahimic (2013), organizational environment has a significant impact on the expressive and management procedures of communiqué, crisis resolution, education, inspiration, competence, output, and efficiency of the institution. The organizational environment of a school influences its output and performance (Hoy \& Hoy, 2006).

One of the elements that may impact instructors' work effectiveness is the organization's climate (Selamat, Samsu, \& Kamalu, 2013). Griffin (2012) believes that one of the components of accomplishing or carrying out the intended mission is job performance. According to Amin, Shah, Ayaz, and Atta (2013), teacher job performance is defined as the instructors' attempts to achieve organizational goals within a certain time frame. The efficacy of a teacher's work performance relates to the attitude that he or she exhibits during the teaching-learning process. Selamat, Samsu, and Kamalu (2013) characterize educator employee productivity as the efficacy and efficiency with which instructors carry out their responsibilities, as well as they argue that high-quality student performance is the result of successful teachings. Teachers' work performance may be assessed using a variety of attitudes and feelings such as professional difficulties, career meaningfulness, occupational responsibility, job dedication, and motivation (Chan, 2008). Moreover, Srivastava and Barmola (2011) believe that motivation is the primary factor that motivates employees to put up true effort and energy in completing their assigned tasks. For the achievement of organizational goals, Gomes, Asseiro, and Ribeiro (2013) noted that motivation is the desire to work at a high degree of individual effort, which leads to satisfaction of their needs and requirements. Motivation impacts the organizational climate's performance (Noordin, Omar, Sehan, \& Idrus, 2010), since it creates an environment that stimulates the organization's workforce (Watkin \& Hubbard, 2003). According to Iqbal (2008), commitment is the reflection of workers' excitement and behavior in the long term to provide their energy to the business via actions and decisions. Commitment, according to Noordin, Omar, Sehan, and Idrus (2010), is the workforce's emotive attachment to, acknowledgment of, and involvement in the company. Commitment is defined by a strong belief in and acceptance of the organization's goals and standards, as well as the willingness to put out substantial effort in favor of the organization and a strong desire to stay connected to it (Raman, Ling,\& Khalid, 2015). Previous studies have shown that there is a strong link between organizational commitment and characteristics of organizational climate; similarly, an 
Vol. II, Issue 3, Oct - December 2021

ISSN No: (ONLINE): 2710-043

www.irjei.com
International Research Journal of Education and Innovation

ISSN No: ISSN (PRINT): 2710-0448

DOI: https://doi.org/10.53575/irjei.v2.03(21)6.67-78

Investigating the Organizational Climate of Secondary Schools ...

organization's efficiency and effectiveness are dependent on the right leadership, inspiration, and administration (Noordin, Omar, Sehan, \& Idrus 2010). Climate has also been identified as a major transitional element between motivation and employees' skillfulness, as well as a substantial component of performance-related factors in previous studies (Rudasill, Snyder, Levinson,\& Adelson, 2018). Productivity, profit, and service quality, as well as pro-social activities, organisational citizenship performance, job happiness, job dedication, creativity, and compassionate human connections, are examples of such factors (Vashdi, Gadot, \& Shlomi, 2013).

The evaluation of related literature provided an overview of organizational climate and its influence on secondary school organizational performance. In the worldwide setting, research has mostly focused on the industrial sector, health, and education. There have been few studies on the Asian continent, but the topic is one of the least explored in our nation, Pakistan. Furthermore, there is a paucity of research papers and literature in Pakistani contexts on organizational climate and its influence on school performance. As a result, it is expected that this study will address the vacuum by producing useful literature on the subject, developing a practical strategy for the development of school organizational environments, and motivating researchers to do research in the Context of Pakistan.

\section{Objectives of the Study}

1. To investigate secondary schools' organizational climate.

2. To determine the link between the various aspects of organizational climate.

\section{Significance of the Study}

The study raises educational stakeholder knowledge of the relevance of organizational climate in secondary schools. It brings awareness among school management teams on the importance of school climate and its influence on principals, management teams, and instructors. It assists school administrators, principals, and teachers in assisting schools in developing ways to improve the organizational environment of their schools. The research also benefits secondary school educators by fostering a good working environment. It provides recommendations to policymakers for the creation and enhancement of the organizational climate in schools. Furthermore, the study is unique in that it encourages school administrators and instructors to focus on the school environment in order to improve learning activities in their classrooms.

\section{Method and Procedure Design of the Study}

This research is a descriptive survey that aimed to analyze the current state of the phenomena, namely the organizational environment of secondary schools in the province. For a quantitative description of a large number of respondents' attitudes, habits, opinions, or trends, descriptive survey design is the best option (Creswell, 2013). Furthermore, the statistical approach of correlation was utilized to determine the degree of link between the various aspects of organizational climate. Quantitative data was gathered from a random sample of individuals through the use of a questionnaire.

\section{Population of the Study}

The study's participants were all secondary school principals and educators in Khyber 
Vol. II, Issue 3, Oct - December 2021

ISSN No: (ONLINE): 2710-043

www.irjei.com
International Research Journal of Education and Innovation

ISSN No: ISSN (PRINT): 2710-0448

DOI: https://doi.org/10.53575/irjei.v2.03(21)6.67-78

Investigating the Organizational Climate of Secondary Schools ...

Pakhtunkhwa (KP). There are 2639 secondary schools in khyber pakhtunkhwa, with 2639 principals, and 39182 instructors (ASR, 2015). The following graph depicts the number of schools in the target region by type, gender, and location

\section{Sample and Sampling of the Study}

The province of Khyber Pakhtunkhwa is split into five administrative zones. Due to the population's geographical dispersion, the study used a multi-stage cluster sampling technique. Except for zone one (1), which was not a part of the province, the researcher chose one district at random from each zone. Peshawar, Swat, Mansehra, and D.I. Khan were the districts chosen at random. A total of 50 schools were chosen at random, including 37 secondary and 13 upper secondary schools. Then, from all of these schools, all 50 principals and 326 teachers were chosen, which comprising 376 participants.

\section{Instrument of Data Collection}

The data was collected using the Organizational Climate Description Questionnaire for Secondary Schools (OCDQ-RS). The OCDQ, which was shaped by Halpin and Croft and amended by Hoy (2009), was modified to the local context and used to collect information about school climate. The OCDQ describes five dimensions of school climate: supportive principal, directive principal behavior, engaged teacher behavior, frustrated teacher behavior, and intimate teacher behavior, which divide climate into two categories: the first two dimensions depict principal behavior, while the remaining three describe teacher behavior.

Validity of an instrument refers to a tool's capacity to measure what it claims to measure (Chan \& Idris, 2017). Following the construction of research instruments, the researcher offered the tool for examination by specialists with expertise of the research in order to determine its validity. They assessed the instruments' suitability and technical rigor. The instruments were pilot tested, and Cronbach's Alpha was used to determine the tool's reliability. The reliability coefficient was determined to be more than the acceptable cutoff value (0.50), as Quaigrain and Arhin (2017) said that the appropriate reliability value is approximately greater than 0.50 or 0.60 . The Organizational Climate Description Questionnaire (OCDQ) has a reliability of 0.873 .

\section{Data Collection and Analysis Procedure}

The researcher gathered information for the study by giving the Organizational Climate Description Questionnaire for Secondary Schools (OCDQ-RS) to secondary school principals and instructors. The data was analyzed using the Statistical Package for Social Sciences (SPSS) version 20, using Mean, Standard Deviation, Regression, and Pearson's correlation as the methods of analysis. To summarize the measurement of different variables related to organizational climate, regression was used to predict the impact of one facet of organizational climate on the others, and Pearson's product correlation co-efficient was used to explore the strength of relationship between the variables and test hypotheses. 
Vol. II, Issue 3, Oct - December 2021

ISSN No: (ONLINE): 2710-043

www.irjei.com
International Research Journal of Education and Innovation

ISSN No: ISSN (PRINT): 2710-0448

DOI: https://doi.org/10.53575/irjei.v2.03(21)6.67-78

Investigating the Organizational Climate of Secondary Schools ...

\section{Results}

Table 1 Supportive Principal Behavior

\begin{tabular}{lcccc}
\hline \multicolumn{1}{c}{ Statements } & Mean & S.D & Chi-square & P-value \\
\hline Setting example by self-hard work & 2.66 & 1.17 & 14.56 & .000 \\
Giving respects to teachers & 2.82 & 1.15 & 43.13 & .000 \\
Principal informally helps teachers & 2.37 & .99 & 34.41 & .000 \\
Explaining reasons for teachers' criticism & 2.52 & 1.04 & 12.06 & .000 \\
Availability after school to assist teachers & 2.39 & 1.19 & 15.94 & .000 \\
Use of criticism for reformation & 2.59 & 1.08 & 5.17 & .000 \\
Caring for teachers' personal welfare & 2.48 & 1.01 & 23.42 & .000 \\
Cumulative & 17.78 & 5.04 & 106.85 & .000 \\
\hline
\end{tabular}

The principals' supporting conduct in the school atmosphere is shown in Table 1. The mean values of 2.82, 2.66, 2.59, and 2.52 with standard deviations of $1.15,1.17,1.08$, and 1.04 indicate that respondents believe that principals' respects teachers, sets an example by working hard himself, provides constructive feedback, and explains why teachers are being criticized. The replies are dispersed around the mean. The cumulative mean score of 17.78 with a standard deviation of 5.04 indicates that, when it comes to the schools' organizational environment, teachers believe that the principal's behavior is generally supportive. The results were significant whilst using the Chi-square test.

It was discovered that the behaviors of secondary school principals are supportive in schools when it pertains to the organizational environment of the schools.

Table 2 Directive Principal Behavior

\begin{tabular}{lcccc}
\hline \multicolumn{1}{c}{ Statements } & Mean & S.D & Chi-square & p-value \\
\hline Head dominates teachers' meetings & 3.11 & 1.09 & 151.40 & .000 \\
Head rules with an iron hand & 2.89 & 1.11 & 50.84 & .000 \\
Head observes teachers' work & 2.67 & 1.12 & 11.52 & .000 \\
Head personally assess teachers' actions & 2.65 & 1.07 & 9.69 & .000 \\
Head is authoritarian & 2.94 & 1.11 & 73.23 & .000 \\
Head supervises teachers regularly & 2.62 & 1.04 & 13.31 & .000 \\
Head listens less and talks more & 2.82 & 1.10 & 31.42 & .000 \\
Cumulative & 19.70 & 53.64 & 145.88 & .000 \\
\hline
\end{tabular}

Table 2 expresses the directive behavior of the principal in the school climate. The mean values of $3.11,2.94,2.89,2.82,2.67,2.65$ and 2.62 with standard deviations 1.09, 1.11, 1.11, $1.10,1.12,1.07$ and 1.04 shows that respondents viewed that principal dominates principalteachers' meetings, principal is autocratic, rules with an iron hand, talks more than listens, monitor teachers' work, closely check teachers' activities and supervises teachers closely. The responses are scattered from means.

The cumulative mean score of 19.70 with standard deviation 53.64 shows that regarding the 
Vol. II, Issue 3, Oct - December 2021

ISSN No: (ONLINE): 2710-043

www.irjei.com
International Research Journal of Education and Innovation

ISSN No: ISSN (PRINT): 2710-0448

DOI: https://doi.org/10.53575/irjei.v2.03(21)6.67-78

Investigating the Organizational Climate of Secondary Schools ...

organizational climate of the school, teachers viewed that most of the times the behavior of the principal is autocratic in the school. Applying the Chi-square test the findings were significant. In relation to the organizational climate of the schools, it identified that the behaviors of the principals at secondary level are directive and autocratic in schools.

Table 3 Engaged Teachers Behavior

\begin{tabular}{lcccc}
\hline \multicolumn{1}{c}{ Statements } & Mean & S. D & Chi-square P-value \\
\hline Teachers address individual problems of students & 1.85 & .96 & 131.93 & .000 \\
Teachers have pride in their school & 2.80 & 1.14 & 32.25 & .000 \\
Students influence school programs/activities & 2.37 & 1.13 & 7.38 & .000 \\
Teachers are friendly with students & 2.78 & 1.09 & 118.93 & .000 \\
Teachers are helpful and supportive for each other & 2.95 & 1.05 & 67.19 & .000 \\
Pupils use logical reasoning for solving problems & 2.28 & .99 & 47.38 & .000 \\
The morale of teachers is high & 2.82 & 1.04 & 32.12 & .000 \\
Teachers really enjoy working here & 2.73 & 1.07 & 17.43 & .000 \\
Students are trusted in independent work & 2.24 & 1.02 & 28.00 & .000 \\
Show respect for personal competence of colleagues & 2.83 & 1.07 & 32.49 & .000 \\
Cumulative & 25.65 & 6.28 & 129.75 & .000 \\
\hline
\end{tabular}

Table 3 reveals the engaged behavior of the teachers. The mean values of $2.95,2.83,2.82$, 2.80, 2.78 and 2.73 with standard deviations 1.05, 1.07, 1.04, 1.14, 1.09 and 1.07 demonstrate that teachers are helpful and supportive, show respect for personal competence of colleagues, have high morale, have pride in their school, friendly with students and enjoy working in their schools. The responses are scattered from means.

The cumulative mean score, i.e. 25.65 with standard deviation 6.28 shows that regarding the organizational climate of the school, teachers viewed that teachers have engaged behavior in the school. Applying the Chi-square test the findings were significant. Referring to organizational climate it is acknowledge that the behavior of the teachers at secondary level is engaged in schools.

Table 4 Frustrated Teachers Behavior

\begin{tabular}{lcccc}
\hline \multicolumn{1}{c}{ Statements } & Mean & S. D & Chi-Square & P-value \\
\hline Teachers' behaviors in school is annoying & 1.91 & 1.11 & 141.44 & .000 \\
Teachers' work load is too heavy & 2.35 & 1.05 & 13.94 & .000 \\
Additional responsibilities disturb teaching tasks & 2.19 & 1.02 & 39.86 & .000 \\
Teachers dislike fellow teachers' criticism in & 1.97 & 1.08 & 84.06 & .000 \\
meetings & 2.14 & .98 & 54.22 & .000 \\
There is too much administrative paper work & 2.11 & .97 & 82.82 & .000 \\
There are too much assigned duties beside & 12.67 & 3.60 & 255.15 & .000 \\
teaching & & & & \\
Cumulative & & &
\end{tabular}


Vol. II, Issue 3, Oct - December 2021

ISSN No: (ONLINE): 2710-043

www.irjei.com
International Research Journal of Education and Innovation

ISSN No: ISSN (PRINT): 2710-0448

DOI: https://doi.org/10.53575/irjei.v2.03(21)6.67-78

Investigating the Organizational Climate of Secondary Schools ...

Table 4 demonstrates that the responses of teachers about school climate on frustrated teachers' behaviors. The mean values of 2.35, 2.19, 2.14 and 2.11 with standard deviations $1.05,1.02, .98$ and .97 demonstrates that teachers viewed that teachers' workload is too heavy, additional responsibilities disturb teaching tasks, there is burdensome administrative work and excessive non-teaching activities. The responses are scattered from means. The finding reveals that the respondents viewed that the behavior of the teachers at secondary level is not frustrated.

The cumulative mean score of 12.67 with standard deviation 3.60 demonstrated that teachers viewed that the behavior of teachers in secondary schools is sometimes frustrated. Applying the Chi-square test the findings were significant. It identified that the behavior of teachers in secondary schools is not a frustrated one.

Table 5 Intimate Teachers Behavior

\begin{tabular}{lcccc}
\hline \multicolumn{1}{c}{ Statement } & Mean & S. D & Chi-Square & P-value \\
\hline Teachers' have collegiality in the school & 2.53 & 1.09 & 10.80 & .013 \\
Teachers have close social relations & 2.68 & 1.02 & 26.36 & .000 \\
Give invitations for visiting homes of each other & 2.06 & 1.01 & 60.52 & .000 \\
Teachers regularly meet in society & 2.52 & 1.09 & 88.65 & .000 \\
Cumulative & 9.68 & 2.78 & 3.21 & .360 \\
\hline
\end{tabular}

Table 5 illustrates the responses of teachers regarding intimate teachers' behavior. The mean scores of 2.68, 2.53 and 2.52 with standard deviations 1.02, 1.09 and 1.09 demonstrates that teachers have collegiality in the school, have close social relations, give invitations for visiting homes of each other and regularly meet in society.

The cumulative mean score of 9.68 with standard deviation 2.78 demonstrates that there is intimate teachers' behavior in secondary schools. Applying the Chi-square test the findings were significant. It identified that teachers have intimate behavior and friendly working relations in secondary schools.

Table 6 Pearson Correlation among Different Facets of Organizational Climate

\begin{tabular}{cccccc}
\hline Variables & SPB & DPB & ETB & FTB & ITB \\
\hline SPB & 1 & & & & \\
DPB & $.556^{* *}$ & 1 & & & \\
ETB & $.638^{* *}$ & $.614^{* *}$ & 1 & & \\
FTB & $.114^{*}$ & $.336^{* *}$ & $.139^{* *}$ & 1 & \\
ITB & $.506^{* *}$ & $.457^{* *}$ & $.662^{* *}$ & $.229^{* *}$ & 1 \\
\hline
\end{tabular}

**. Correlation is significant at the $0.01 \& 0.05$ level (2-tailed).

Table 6 shows that all the facets of organizational climate are strongly correlated. The figures indicate that supportive principal behavior is strongly correlated with directive principal 
Vol. II, Issue 3, Oct - December 2021

ISSN No: (ONLINE): 2710-043

www.irjei.com
International Research Journal of Education and Innovation

ISSN No: ISSN (PRINT): 2710-0448

DOI: https://doi.org/10.53575/irjei.v2.03(21)6.67-78

Investigating the Organizational Climate of Secondary Schools ...

behavior (.556), engaged teachers behavior (.638), intimate teachers behavior (.506). Similarly directive principal behavior is significantly associated with engaged teacher behavior (.614), frustrated teacher behavior (.336) and intimae teacher behavior (.457). Likewise engaged teacher behavior is strongly linked with intimate teachers' behavior (.662) and frustrated teacher behavior is positively correlated to some extent with intimate teacher behavior (.229). In this way frustrated teacher behavior is weekly correlated with supportive principal behavior (.114) and engaged teacher behavior (.139) respectively.

Table 7 Regression Analysis of $\mathrm{OC}$ and its Facets

\begin{tabular}{cccccccccc}
\hline Predictors & $\mathbf{B}$ & $\begin{array}{c}\text { Std. } \\
\text { Error }\end{array}$ & Beta & $\mathbf{t}$ & $\mathbf{p}$-value & $\mathbf{R}$ & $\mathbf{R}^{2}$ & $\begin{array}{c}\text { Adjuste } \\
\mathbf{d ~ R ^ { 2 }}\end{array}$ & $\mathbf{F}$ \\
\hline (Constant) & .000 & .001 & & -.239 & .811 & & & & \\
SPB & .207 & .000 & .311 & 481.772 & .000 & & & & \\
DPB & .205 & .001 & .239 & 363.201 & .000 & & & & \\
& & & & & & & & & \\
ETB & .294 & .001 & .385 & 504.094 & .000 & 1.000 & 1.000 & 1.000 & 896300.35 \\
(p.v..000) & \\
FTB & .177 & .000 & .221 & 431.559 & .000 & & & & \\
ITB & .030 & .000 & .172 & 265.401 & .000 & & & & \\
\hline
\end{tabular}

a. Dependent Variable: OC

b. Predictors: (Constant), ITB, FTB, SPB, DPB, ETB

Data in the above table shows the contribution of all the sub facets of organizational climate that these facets have a significant influence at $F=896300.35$ with $p$ value $=.000$. The result also shows that the linear combination of the one dependent and five independent variables, with the correlation coefficient $(\mathrm{R}=1.00)$ has a strong influence and thus the model is significant. Moreover $\mathrm{R}^{2}=1.000$ reveals that $100 \%$ difference is found in the model for the respondents, with a beta $.311, .239, .385, .221, .172$ for supportive principal behavior, directive principal behavior, engaged teacher behavior, frustrated teachers behavior and intimate teacher behavior respectively. It means that one percent changes in independent variables caused 100 percent changes in dependent variable.

\section{Discussion}

Organizational climate is one of the conventional measures considered to reflect the effectiveness of schooling (Marsh et al., 2012). The aim of the study was to explore and examine the organizational climate of secondary schools. For this purpose the first objective was "To explore the organizational climate of secondary schools" while the hypothesis was that "there is no significant variation in the organizational climate of different secondary schools" For the exploration of organizational climate and investigating the variation in the organizational climate of different secondary schools mean scores and standard deviation were used. It revealed that there is great variation in the organizational climate of various secondary schools, i.e. different schools have different climate. So, it means that there is a significant variation in the organizational climate of secondary schools, so the null hypothesis 
Vol. II, Issue 3, Oct - December 2021

ISSN No: (ONLINE): 2710-043

www.irjei.com
International Research Journal of Education and Innovation

ISSN No: ISSN (PRINT): 2710-0448

DOI: https://doi.org/10.53575/irjei.v2.03(21)6.67-78

Investigating the Organizational Climate of Secondary Schools ...

that there is insignificant variation in the organizational climate of secondary school is rejected.

The findings are in agreement with the study of Zander (2012) that there is variation in the climate of different schools. The research of Fisher, Fisher, Arsenault, Jacob, and Barnes-Najor (2020) further support the findings and stated that school climate is largely dependent on each individual experiences and characteristics and various school climate scores indicate that each school is significantly different from other.

The second objective was to find out the relationship among the different facets of organizational climate. Pearson correlation among different facets of organizational climate pointed out that supportive principal behavior is strongly correlated with directive principal behavior (.556), engaged teachers behavior (.638), intimate teachers behavior (.506). Directive principal behavior is significantly associated with engaged teacher behavior (.614), frustrated teacher behavior (.336) and intimae teacher behavior (.457). Engaged teacher behavior is strongly linked with intimate teachers' behavior (.662) and frustrated teacher behavior is positively correlated to some extent with intimate teacher behavior (.229). Frustrated teacher behavior is weakly correlated with supportive principal behavior (.114) and engaged teacher behavior (.139).

\section{Recommendations}

The following recommendations were given based on the study's findings to manage the organizational climate of secondary schools, solve difficulties, and establish a conducive learning environment in the institutions.

1. Organizational climate is a relatively new area, it may be taught as a subject in all teacher training institutes and education departments/faculties at universities to help educational leaders and instructors build conceptual understanding.

2. Currently, the Educational Monitoring Authority (EMA) does not include organizational environment as a factor in school development and advancement. As a result, the government may incorporate organizational climate in the school's evaluation system (assessment).

3. Because school authorities and educational leaders are oblivious of research results on organizational climate, a resource/research institute should then be established to offer and distribute new research-based information on school climate to school administrators.

4. School principals play a critical role in the creation of a healthy school climate (learning environment); for this reason, training programmers as well as in refresher courses may be offered to help establish a healthy school climate.

5. The education department may be given authority to create a school improvement forum in which schools' organize professionals debate on various challenges in educational institutions and provide solutions for fostering a positive school atmosphere that would offer a conducive learning environment for students.

\section{References}

1. Adejumobi, F. T., \& Ojikutu, R.K. (2013). School climate and teacher job performance in Lagos state Nigeria. Discourse Journal of Educational Research, 1(2), 26-36. 
Vol. II, Issue 3, Oct - December 2021

ISSN No: (ONLINE): 2710-043

www.irjei.com
International Research Journal of Education and Innovation

ISSN No: ISSN (PRINT): 2710-0448

DOI: https://doi.org/10.53575/irjei.v2.03(21)6.67-78

Investigating the Organizational Climate of Secondary Schools ...

2. Amin,M., Shah, R., Ayaz, M.,\& Atta, M. A. (2013).Teachers' job performance at secondary level in Khyber Pakhyunkhwa, Pakistan. Gomal University Journal of Research, 29(2), 100-104.

3. Andrews, R., Boyne, G., \& Walker, R. M. (2011). The impact of management on administrative and survey measures of organizational performance. Public Management Review, 13(2), 227-255.

4. Armstrong, A. (2003). Corporate governance: Can governance standard change corporate behavior?Australian Journal of Professional and Applied Ethics, 5(2), 1-10.

5. Borins, S. (2000). Loose cannons and rule breakers, or enterprising leaders? Some evidence about innovative managers.Public Administration Review, 60, 490-499.

6. Chan, O. B (2008). Influences of workplace conditions on teacher's job satisfaction. Journal of Occupational Psychology.53(7) 39-52.

7. Creswell, W. (2013). Research design: Qualitative, quantitative and mixed methods approach (2nd ed.). Thousand Oaks: Sag Publishers.

8. EMIS. (2015). Annual statistical report of government schools 2015-16. Government of Khyber Pakhtunkhwa, Pakistan.

9. Freiberg, H.J., \& Stein T.A. (1999). School climate; Measuring, improving and sustaining healthy learning environments. London:Falmer Press.

10. Gerber, F. J. (2003). Die involved van organizational climate op works motivation [The influence of organizational climate on work motivation]. Unpublished MCommdissertation, University of South Africa, Pretoria.

11. Ghanbari, S., \& Eskandari, A. (2015). Organizational climate, job motivation and organizational citizenship behavior. International Journal of Management Perspective, 1(3), 1-14.

12. Gomes, D. R., Asseiro, V., \& Ribeiro, N. (2013).Triggering employee motivation in adverse organizational contexts: "Going the extra mile" while holding hands with uncertainty? Business and Management Research. 2(1), 41-54.

13. Griffin, R.W. (2012).Management. Mason, USA: South- Western College Pub.

14. Hoy, W. K., \& Hoy, A. W. (2006). Instructional leadership: A research based guide to learningin schools ( $2^{\text {nd }}$. ed.). Boston: Pearson.

15. Hoy, A. W., \& Hoy, W. K. (2009). Instructional leadership: A research-based guide to learning in schools (3rd ed.). Pearson Inc

16. Hoy, W. K., \& Miskel, C. G. (2008). Educational administration: Theory, research, and practice (8th ed.). New York: McGraw Hill

17. Iqbal, A. (2008). Organizational climate and employees' commitment: A study of the Pakistani Knitwear industry. Estableciendo Puentes en Una Economía Global, 1, 3238.https://www.researchgate.net/publication/28231998

18. Kelley, E.A. (1980). Improving school climate: Leadership techniques for educators. Reston,VA: The National Association of Secondary School Principals.

19. Kopelman, M. L; Brief, E.F.,\&Guzzo, R. T (2000). Congruence between individual needs, organizational climate, job satisfaction and performance. Academy of Management Journal.18(3) 149-165.

20. Maamari, B. E., \& Majdalani, J. F. (2017). Emotional intelligence, leadership style and organizational climate. Organizational Analysis, 25(2), 327-345.

21. Marsh, H. W., Lüdtke, O., Nagengast, B., Trautwein, U., Morin, A. J., Abduljabbar, A. S., ～\& Köller, O. (2012). Classroom climate and contextual effects: Conceptual and methodological issues in the evaluation of group-level effects. Educational Psychologist, 47(2), 106-124.

22. McCarley, T. A., Peters, M. L., \& Decman, J. M. (2016). Transformational leadership related to school climate: A multi-level analysis. Educational Management Administration \& Leadership, 44(2), 322342.

23. Mitchell, M. M., Bradshaw, C. P., \& Leaf, P. J. (2010). Student and teachers, perceptions of school climate: A multilevel exploration of patterns of discrepancy. Journal of School Health, 80(6), 271279.

24. Noordin, F., Omar, S., Sehan, S.,\& Idrus, S. (2010). Organizational climate and its influence on 
Vol. II, Issue 3, Oct - December 2021

ISSN No: (ONLINE): 2710-043

www.irjei.com
International Research Journal of Education and Innovation

ISSN No: ISSN (PRINT): 2710-0448

DOI: https://doi.org/10.53575/irjei.v2.03(21)6.67-78

Investigating the Organizational Climate of Secondary Schools ...

organizational commitment. International Business \& Economics Research Journal, 9(2), 1-10.

25. Okoli, I. E. (2018). Organizational climate and job satisfaction among academic staff: Experience from selected private universities in southeast Nigeria. International Journal of Research in Business Studies and Management, 5(12), 36-48.

26. Osman, N. W., \& Kamis, A. (2019). Innovation leadership for sustainable organizational climate in institution of technical and vocational education and training (TVET) in Malaysia. Asian Journal of Assessment in Teaching and Learning, 9(1), 57-64.

27. Pretorius, S., \& Villiers, E. D. (2009). Educators' perceptions of school climate and health in selected primary schools. South African Journal of Education, 29(1). Doi:10.1590/s025601002009000100003

28. Quaigrain, K., \& Arhin, A. K. (2017).Using reliability and item analysis to evaluate a teacherdeveloped test in educational measurement and evaluation. Cogent Education, 4(1), 1301013.

29. Rahimić, Z. (2013). Influence of organizational climate on job satisfaction in Bosnia and Herzegovina companies. International Business Research.6(3), 129-139.

30. Raman, A.,Ling, C.C.,\& Khalid, R. (2015).Relationship between school climate and teachers' commitment in an excellent school of Kubang Pasu district, Kedah, Malaysia. Mediterranean Journal of Social Sciences. 6 (3), 163-173.

31. Rudasill, K. M., Snyder, K. E., Levinson, H., \& Adelson, J. L. (2018). Systems view of school climate: A theoretical framework for research. Educational psychology review, 30(1), 35-60.

32. Schneider, B., González-Romá, V., Ostroff, C., \& West, M. A. (2017). Organizational climate and culture: Reflections on the history of the constructs in the Journal of Applied Psychology. Journal of applied psychology, 102(3), 468.

33. Sehan, S., \& Idrus, S. (2010). Organizational climate and its influence on organizational commitment. International Business \& Economics Research Journal (IBER), 9(2) 5-16.

34. Selamat, N., Samsu, N. Z.,\& Kamalu, N. S. M. (2013). The impact of organizational climate on teachers' job performance. Educational Research, 2(1), 71-82.

35. Srivastava, S. K., \& Barmola, K. C. (2011). Role of motivation in higher productivity. Management Insight, 7(1), 88-99.

36. Stringer, R. A. (2002). Leadership and organizational climate: The cloud chamber effect. New Jersey: Prentice Hall, Upper saddle River.

37. Vashdi, D. R., Vigoda-Gadot, E., \&Shlomi, D. (2012). Assessing performance: The impact oforganizational climates and politics on public schools' performance. Public Administration, 91(1), 135-158. doi:10.1111/j.1467-9299.2011.01968.x

38. Vigoda, E. \& Golembiewski, R. T.(2001). Citizenship behavior and the spirit of new managerialism: A theoretical framework and challenge for governance. American Review of Public Administration, 31, 273-95

39. Vigoda-Gadot, E., \& Kapun, D. (2005). Perceptions of politics and perceived performance in public and private organizations:A test of one model across two sectors. Policy and Politics, 33, 251-76.

40. Villiers, E. D. (2006). Educators' perceptions of school climate in primary schools inthe Southern Cape.University of South Africa.

41. Watkin, C., \& Hubbard, B. (2003). Leadership motivation and the drivers of share price: The business case for measuring organizational climate. Leadership and Organization Development Journal, 24 (7), 380-386.

42. Walker, R. M. \& Boyne, G. A.(2009). Determinants of performance in public organizations. Public Administration, 87, 433-439.

43. Zander, K. (2012). Relationships between school climate and student performance: School-and student-level analyses (Doctoral dissertation, University of Illinois at Chicago). 